\title{
E - Customers perspective about digital banking in Ahmedabad city
}

\author{
Ms. Vidhi K Davda \\ PGDM Student \\ (St. Kabir Institute of Professional Studies, Ahmedabad)
}

\begin{abstract}
:
The digitalization of banks has helped to reduce manual work and human errors in the banking field. Digitalization in banking sectors made the work easy. The rapid growth of digitalization in banking is an advantage to use the resources efficiently and give personalized services to the end-user. Digital banking has many advantages. The future of digital banking is bright and the millennials (generation $\mathrm{Y}$ ) are the one adopts the digitalization faster. This research is based on the primary data and data is collected with the help of a structured questionnaire.
\end{abstract}

Keywords: Digital banking, E - customers,Perception,Ahmedabad city.

\section{Introduction:}

Financial activities are an integral part ofthe day to day life.Digital banking referred to as the services provided by banks on the digital platform which helps customers to reach the bank at convincing. Digital banking is also known as online banking or Internet banking. It is the shift from typical traditional banking to digital banking that has been gradual and stays the ongoing process.

The first step towards digital banking is ATMs which was in the 1960s. In the year 1990,the internet became easily available and online banking started. More Than $60 \%$ of the population use smartphones and prefer to use digital banking or the digital platform for most of the things. 
According to a study which was conducted in $2015,44 \%$ believed that digital banking creates a competitive advantage, $47 \%$ to see the potential to improve customer relationship with the help of digital banking, $32 \%$ believed that it is useful to acquire new customers and only $16 \%$ gave an opinion to have potential towards cost-saving.

There are various benefits of using Digital banking are Business efficiency, Cost savings, Increased accuracy, Improved competitiveness, Greater agility, and Enhanced security. The automation increases efficiency and reduces the paperwork which also avoids the storage of paper that can be replaced or can be occupied with technology. There are many problems faced by banks to invest in digital backend work culture like some bank products with are newly launched and face difficulty to automate, change in government regulations which arecomplex nature, etc. A digital bank ought to facilitate all useful levels of banking on all service delivery platforms. In other words, it ought to have all the same features as a head office, branch office, online service, financial institution cards, ATM and point of sale machines.

The decision to add extra digital solutions at all operational levels which will have a major impact on bank and their economic stability. Very few banks have adopted the changes and are aiming to move within 6 months towards the end to end automation.

\section{Literature review:}

Dr. Datta K. Saroj (1970)conducted empirical Investigation in India and explained the customer perception, demographic factors, trends of e-banking, various factors affecting the e-banking to adult customers and also indicated the concern towards security and safety regarding Indian context.

McDougall H.G. Gordon (1996) in the paper titled Determinants of customer satisfaction in retail banking explained about customer satisfaction, customer retention, future intentions of retail banking, marketing of the different products as per customer requirement, and different dimensions of service quality for the customer in Canada.

Liberatore J. Matthew J. (1997) explained the adoption pattern and the issues regarding implementations of digital technology with the banking and insurance companies. This was done with a survey of 250 largest insurance companies and the 250 largest banks listed in the Ward Business Directory out of which only 75 banks and 62 insurance companies for a total of 137 completed the questionnaire and gave a perfect response.

Sathye Milind (1999) in the paper titled Adoption of Internet banking by Australian consumers explained the factors affecting the adoption of Internet banking.

As per, Smith Anne (2000) customer satisfaction, customer loyalty, customer service, and the model considers the normal teller technique or the automated things in e-banking. 
Aladwani M Adel (2001) in the paper titled online banking: a field study of drivers, development challenges, and expectations explained through the quantitative methods and the survey was conducted among 8 IT managers, 8 senior managers, and 64 potential customers of online banking which gave the information on the key drivers, development challenges, and expectations and the perception of the bank executives towards all the challenges.

Bradley Laura (2002) in the paper titled A Delphi study of the drivers and inhibitors of Internet banking explained the Delphi method, marketing, distribution channels, internet banking, and the innovation. This also explained the factors driving and inhibiting Internet banking.

Ibbotson Patrick (2003) explained about the examination of the level of usage of e-banking and satisfaction with the channels of e-banking with the help of interviews and surveys of 250 respondent of small to medium-sized enterprises (SME) of Northern Ireland.

Kolodinsky M. Jane (2004) in the paper titled The adoption of electronic banking technologies by US consumers explained about the effects and the intentions of the e-banking and measured the financial services with the help of telephonic surveys of 500 households and to also know the customer behavior in the United States of America.

Floh Arne (2006) in the paper titled What Keeps the E-Banking Customer Loyal? A Multigroup Analysis of the Moderating Role of Consumer Characteristics on E-Loyalty in the Financial Service Industry explained about the importance of online banking and customer loyalty of online customers with the help of trust factor, quality of the website, quality of the service and overall satisfaction. It was done through a survey and more than 2000 respondents gave their feedback for the same.

\section{Research Objective :}

To examine and analyze the perception of e - customers concerning digital banking in Ahmedabad city.

\section{Research Methodology :}

Reasons for using digital banking, digital banking technologies, and the problems faced while using banking technologies were considered for the preparation of the questionnaire.Responses were collected from bank customers who are using digital banking. The responses were collected to measure the satisfaction level and the perception of digital banking services. The survey was conducted to measure the perspective of $\mathrm{E}-$ customers concerningsatisfaction level of $403 \mathrm{E}$ - customers across Ahmedabad city. Non-probability convenience sampling was used to select respondents.A self-administered questionnaire was devised by the researcher. The target questions in the questionnaire are the reasons for using 
digital banking such as perceived value, convenience, functional quality, service quality,brand trust,employee-customer engagement, perceived risk, innovation in digital banking \& loyaltythe second focus was the recent technology used in digital banking and enhance the performance such as virtual banking, biometric technology, artificial intelligence, blockchain, robotics\& Bluetooth beaconsand the third focus was the problems faced to adopt the digital platform for banking such Not user-friendly technology, Not reliable services, Not responsiveservices\&Security issues. The questions asked in the research are based on the 5 points Likert Scale of $(-1)=$ Strongly Disagree, $0=$ Disagree, $1=$ Neutral, 2= Agree, 3= Strongly Agree. Final scores for each criterion are calculated by multiplying the number of responses by the weights of the corresponding response. Out of the 403 questionnaires served 278 who responded were male and 125 were female respondents.

\section{Research Analysis :}

It represents the calculation of the respondent's perception with the help of the ideal and least scores. Ideal scores are calculated by multiplying the number of respondents in each category with $(+3)$ and product with the total number of criteria. Least scores calculated by multiplying the number of respondents in each category with $(-1)$ and the product with the number of criteria's in the structured questionnaires.

Table 1 Ideal Score and Least Scores of Respondents

\begin{tabular}{|l|c|c|c|c|}
\hline Category & Equation & Ideal Score & Equation & Least Score \\
\hline E - Customers & $19 \times 3 \times 403$ & 22971 & $19 \times-1 \times 403$ & -7657 \\
\hline
\end{tabular}

Table 2 References of the Respondents

\begin{tabular}{|c|l|c|c|c|c|c|c|}
\hline No. Criteria's & $\begin{array}{c}\text { Strongly } \\
\text { Agree }\end{array}$ & Agree & Neutral & Disagree & $\begin{array}{c}\text { Strongly } \\
\text { Disagree }\end{array}$ & Score \\
\hline \multicolumn{7}{|c|}{ Responses } \\
\hline \multicolumn{7}{|c|}{} & \multicolumn{2}{|c|}{3} & 2 & 1 & 0 & -1 & \\
\hline 1 & Perceived value & 294 & 486 & 58 & 0 & - & 838 \\
\hline 2 & Convenience & 438 & 390 & 59 & 0 & - & 887 \\
\hline 3 & Functional quality & 483 & 312 & 80 & 0 & - & 875 \\
\hline 4 & Service quality & 540 & 306 & 59 & 0 & - & 905 \\
\hline 5 & Brand Trust & 546 & 264 & 75 & 0 & -1 & 884 \\
\hline 6 & $\begin{array}{l}\text { Employee customer } \\
\text { engagement }\end{array}$ & 237 & 396 & 114 & 0 & -3 & 744 \\
\hline 7 & Perceived Risk & 150 & 266 & 201 & 0 & -2 & 615 \\
\hline 8 & Innovation in digital banking & 267 & 326 & 143 & 0 & - & 410 \\
\hline 9 & Loyalty & 411 & 364 & 77 & 0 & - & 852 \\
\hline 10 & Virtual Banking & 351 & 476 & 46 & 0 & & 873
\end{tabular}




\begin{tabular}{|l|l|c|c|c|c|c|c|}
\hline 11 & Biometric Technology & 195 & 300 & 159 & 0 & & 654 \\
\hline 12 & Artificial Intelligence & 195 & 338 & 141 & 0 & & 674 \\
\hline 13 & Blockchain & 144 & 192 & 225 & 0 & -12 & 549 \\
\hline 14 & Robotics & 162 & 278 & 169 & 0 & -6 & 603 \\
\hline 15 & Bluetooth Beacons & 114 & 334 & 179 & 0 & -4 & 623 \\
16 & Not user - friendly services & 159 & 404 & 91 & 0 & -12 & 642 \\
\hline 17 & Not reliable services & 117 & 266 & 168 & 0 & -12 & 539 \\
\hline 18 & Not responsive services & 183 & 286 & 140 & 0 & -10 & 599 \\
19 & security Issues & 264 & 344 & 97 & 0 & -11 & 694 \\
\hline
\end{tabular}

Table 3 Aggregate score

\begin{tabular}{|c|l|c|}
\hline No. & \multicolumn{1}{|c|}{ Criteria's } & Score \\
\hline 1 & Perceived value & 838 \\
\hline 2 & Convenience & 887 \\
\hline 3 & Functional quality & 875 \\
\hline 4 & Service quality & 905 \\
\hline 5 & Brand trust & 884 \\
\hline 6 & Employee customer engagement & 744 \\
\hline 7 & Perceived Risk & 615 \\
\hline 8 & Innovation in digital banking & 410 \\
\hline 9 & Loyalty & 852 \\
\hline 10 & Virtual Banking & 873 \\
\hline 11 & Biometric Technology & 654 \\
\hline 12 & Artificial Intelligence & 674 \\
\hline 13 & Block Chain & 549 \\
\hline 14 & Robotics & 603 \\
\hline 15 & Bluetooth Beacons & 623 \\
\hline 16 & Not user - friendly services & 642 \\
\hline 17 & Not reliable services & 539 \\
\hline 18 & Not responsive services & 599 \\
\hline 19 & security Issues & 694 \\
\hline \multirow{2}{*}{ Total scores of Responses } & $\mathbf{1 3 4 6 0}$ \\
\hline Ideal Score & \\
\hline Least Score & 2971 \\
\hline
\end{tabular}

\section{Source: Field survey}




\section{Interpretation with respect to respondents using digital banking :}

As per the present scenario, the total score of the respondent is 13460 . The ideal score for the same case is 22971. The percentage of the Ideal score generated with the help of responses taken from the respondents is $58.5956 \%$. Therefore, in this case, the total score and the least score does not come near. This indicates that the banks which use the digital platform to provide banking facilities have taken the right move towards digitalization but will have to try to reduce the problems faced by the customers while using the digital platform.

\section{Conclusion :}

Technology has a huge impact on the banking sector. Digital banking will help to reduce the manual work of the day to day transactions for the banks. The banking process remains the same but the way of dealing with banking has changed as time changes.Five important factors for customers who are using digital banking services are Convenience, Functional Quality, Service Quality, Brand Trust, and Virtual. Hence can be said that banks are undergoing the process towards tech-savvy modern bank culture.

\section{References :}

1. Dixit, N., \& Saroj, K. (1970). Acceptance of e-banking among adult customers: An empirical investigation in India. The Journal of Internet Banking and Commerce, 15(2), 1-17.

2. Liberatore, M. J., \& Breem, D. (1997). Adoption and implementation of digitalimaging technology in the banking and insurance industries. IEEE Transactions on Engineering Management, 44(4), 367-377.

3. Levesque, T., \& McDougall, G. H. (1996). Determinants of customer satisfaction in retail banking. International journal of bank marketing,14(7),12-20.

4. Sathye, M. (1999). Adoption of Internet banking by Australian consumers: an empirical investigation. International Journal of bank marketing, 17(7), 324-334.

5. Moutinho, L., \& Smith, A. (2000). Modeling bank customer satisfaction through mediation of attitudes towards human and automated banking. International Journal of bank marketing,18(3),124-134. 
6. Dr. Jayantsinh A Sarvaiya, Rajesh P Ganatra (2012). Technology in Banking Insights of E - Customers of Ahmedabad city. Indian Journal of Applied Research. 2(3),78-80.

7. Mr. Rajesh P Ganatra (2012).Internet Banking Adoption Analysis using variables of technology Acceptance Model (TAM): Empirical study of NSE 50 banks Ecustomers in Ahmedabad city paripex. Indian Journal of Research, 1(7), 53-55.

8. Dr. Jayantsinh A Sarvaiya, Rajesh P Ganatra(2014) Internet Banking Acceptance in Ahmedabad city. 3(12), 161-165.

9. Aladwani, A. M. (2001). Online banking: a field study of drivers, development challenges, and expectations. International Journal of Information Management, 21(3), 213-225.

10. Bradley, L., \& Stewart, K. (2002). A Delphi study of the drivers and inhibitors of Internet banking. International Journal of Bank Marketing,20(6),250-260.

11. Ibbotson, P., \& Moran, L. (2003). E-banking and the SME/bank relationship in Northern Ireland. International Journal of Bank Marketing,21(2),94-103.

12. Kolodinsky, J. M., Hogarth, J. M., \& Hilgert, M. A. (2004). The adoption of electronic banking technologies by US consumers. International Journal of Bank Marketing,38(4), 238-259.

13. Floh, A., \& Treiblmaier, H. (2006). What keeps the e-banking customer loyal? A multigroup analysis of the moderating role of consumer characteristics on e-loyalty in the financial service industry. A Multigroup Analysis of the Moderating Role of Consumer Characteristics on E-Loyalty in the Financial Service Industry.(March 26, 2006).

14. Sharma, M. S., \& Halvadia, N. B. (2015). Measuring service quality of internet banking portal in India. Annals of Management Science, 4(2), 29-51. 